\title{
DAMPAK POLA PEREMAJAAN PARTISIPATIF TERHADAP PERKEMBANGAN PERKEBUNAN KARET RAKYAT DI KABUPATEN OGAN KOMERING ULU PROVINSI SUMATERA SELATAN
}

\section{The Impact of Participatory Rubber Replanting Program on Rubber Smallholding Development in Ogan Komering Ulu District, South Sumatra Province}

Lina Fatayati SYARIFA, Dwi Shinta AGUSTINA*, Aprizal ALAMSYAH, dan Iman Satra NUGRAHA

Balai Penelitian Sembawa, Pusat Penelitian Karet Jalan Raya Palembang - P. Balai KM 29, PO BOX 1127 Palembang 30001

*Email: dwishinta_sbw@yahoo.com

Diterima : 27 Februari 2017 / Disetujui : 7 April 2017

\begin{abstract}
Participatory rubber replanting model in Ogan Komering Ulu (OKU) District has been implemented for 10 years. This study was conducted to describe the successful of the model implementation, as well as its impact on rubber smallholding development in OKU district. The study was conducted using a survey method in the villages which were implementing the model. The respondents were selected by Random Sampling Method by taking ten participant farmers and five non-participant farmers in each selected village. The data was analyzed by discriptive analysis. The result showed that the projects had given a positive impact to participant and non-participant farmers. It was seen from the expansion of rubber planting area in the villages, increasing of rubber clonal area owned by farmers, increasing of farmers' knowledge and adoption to rubber technology, and increasing of farmers' access to banking. However, farmers still need an intensive training in terms of disease control and rubber tapping. For rubber replanting program sustainability, the local government had facilitated rubber development program through giving rubber planting material assistance to rubber nursery and rubber farming, as well as training for technical officer and rubber farmers.
\end{abstract}

Keywords: Rubber; impact; replanting; participatory

\section{Abstrak}

Penerapan pola peremajaan karet partisipatif di Kabupaten Ogan Komering Ulu (OKU) telah berjalan lebih kurang 10 tahun. Penelitian ini dilakukan untuk mengetahui keberhasilan penerapan model peremajaan karet partisipatif, serta dampaknya terhadap perkembangan perkebunan karet rakyat di Kabupaten OKU. Penelitian dilakukan dengan metode survei di desa-desa yang menerapkan pola peremajaan karet partisipatif. Pemilihan responden dilakukan secara acak yaitu memilih sepuluh petani peserta program dan lima petani non peserta program yang berada disekitar proyek di setiap desa. Selanjutnya analisis data dilakukan secara diskriptif. Dari hasil pengamatan disimpulkan bahwa proyek peremajaan partisipatif di Kabupaten OKU telah memberikan dampak positif terhadap petani peserta proyek dan lingkungan sekitarnya. Hal ini tampak dari adanya perluasan areal penanaman karet di desa, bertambahnya areal karet klonal yang dimiliki petani, meningkatnya pengetahuan dan adopsi petani peserta dan non peserta terhadap teknologi perkaretan, dan meningkatnya pengetahuan petani dalam akses perbankan. Namun demikian, petani masih memerlukan pelatihan yang lebih intensif dalam hal penyadapan dan pengendalian penyakit karet. Untuk keberlanjutan program peremajaan, pemerintah daerah setempat telah banyak memfasilitasi kebijakan program pengembangan karet melalui pembiayaan program bantuan bibit untuk kebun usaha tani dan pembibitan, serta pelatihan bagi para petugas teknis dan petani karet.

Kata Kunci: Karet; dampak; peremajaan; partisipatif

\section{PENDAHULUAN}

Komoditas karet memiliki peranan penting dalam perekonomian nasional yaitu sebagai sumber pendapatan lebih dari 2,2 juta petani dan memberikan kontribusi yang sangat berarti pada devisa negara yang mencapai sekitar USD 6,9 juta pada tahun 2013 (Badan Pusat Statistik [BPS], 2013; Gabungan Perusahaan Karet Indonesia 
[Gapkindo], 2014; Direktorat Jendral Perkebunan [Ditjenbun], 2014). Provinsi Sumatera Selatan merupakan salah satu sentra karet terbesar di Indonesia dengan luas areal mencapai 1,2 juta $\mathrm{Ha}$ dan produktivitas sekitar $1420 \mathrm{~kg} / \mathrm{Ha} /$ tahun. Luasan tersebut didominasi oleh perkebunan rakyat mencapai $93 \%$ yang sebagian besar merupakan areal karet swadaya. Karet juga menjadi sumber mata pencaharian lebih dari 649 ribu keluarga (KK) petani dan 100 ribu karyawan perusahaan perkebunan di Sumatera Selatan (Pemerintah Provinsi Sumatera Selatan, 2012; Dinas Perkebunan Provinsi Sumatera Selatan [Disbun Provinsi Sumsel], 2013). Dari pengamatan diperoleh data bahwa tahun 1982-2013 di Sumatera Selatan telah terjadi peningkatan total luas areal sebesar 1,98\% per tahun (Tabel 1). Dari peningkatan areal tersebut, terjadi juga peningkatan produktivitas sebesar 2,20\% per tahun (Disbun Provinsi Sumsel, 2013).

Meningkatnya luas areal dan produktivitas karet adalah dampak dari berbagai upaya yang telah dilakukan oleh pemerintah dan pihak terkait melalui proyek pengembangan atau peremajaan karet rakyat yang telah dilaksanakan pada sentrasentra karet. Dalam mendukung gerakan peremajaan karet rakyat tersebut, Pusat Penelitian Karet - Balai Penelitian Sembawa telah menghasilkan konsepsi Model Peremajaan Karet Partisipatif yang dapat digunakan sebagai kerangka kerja untuk pelaksanaan program percepatan peremajaan pada wilayah sentra karet tradisional (existing) di Indonesia (Hendratno, Woelan, \& Fathurrohman, 2015). Model percepatan pengembangan atau peremajaan karet partisipatif dikembangkan berdasarkan upaya peningkatan partisipasi dan pemberdayaan masyarakat secara lebih optimal. Sasaran akhir dari penerapan model adalah percepatan pembangunan atau peremajaan karet oleh petani dengan menggunakan teknologi anjuran guna memperbaiki produktivitas dan meningkatkan pendapatan petani. Strategi yang ditempuh adalah melalui pendekatan wilayah "maju" dan "belum maju" (Supriadi, Nancy, Wibawa, \& Gunawan, 2006).

Model Peremajaan ini secara terbatas telah diterapkan di beberapa kabupaten sentra karet di Indonesia sejak tahun 2001 (Supriadi \& Nancy, 2005), salah satunya di Kabupaten Ogan Komering Ulu (OKU) yang kemudian pada perkembangannya mengalami pemekaran wilayah menjadi tiga kabupaten yaitu: OKU Induk, OKU Timur dan OKU Selatan. Komponen model peremajaan karet partisipatif yang telah diterapkan yaitu : penyediaan fasilitas kredit peremajaan untuk pembangunan kebun beserta paket program pendukung lainnya. Paket kredit ini dimungkinkan berkat terjalinnya kerjasama antara Pemda OKU dan Bank Sumsel yang terbentuk dalam Nota Kesepakatan Kerjasama. Dalam Nota Kesepakatan tersebut disebutkan bahwa Bank Sumsel berkewajiban memberikan pinjaman kredit kepada petani peserta proyek peremajaan, sedangkan Pemda OKU berkewajiban menyediakan dana dalam bentuk simpanan giro tetap (beku) selama masa kredit untuk membiayai kegiatan pembangunan dan pemeliharaan kebun petani peserta seluas 500 Ha di Kabupaten OKU pada tahun 2003 (Supriadi et al., 2003).

Tabel 1. Produktivitas karet di Sumatera Selatan, 1982-2013

Table 1. The rubber productivity in South Sumatera, 1982-2013

\begin{tabular}{lcrc}
\hline \multirow{2}{*}{$\begin{array}{c}\text { Uraian } \\
\text { Discription }\end{array}$} & \multicolumn{2}{c}{$\begin{array}{c}\text { Tahun } \\
\text { Year }\end{array}$} & $\begin{array}{c}\text { Rata-rata pertumbuhan/tahun } \\
\text { Average growth per year } \\
(\%)\end{array}$ \\
\cline { 2 - 3 } & \multicolumn{1}{c}{1982} & 2013 & 1,98 \\
Luas Total (Ha) & 474.851 & 1.232 .038 & 2,04 \\
Luas TM (Ha) & 277.054 & 756.377 & 2,85 \\
Produksi & 125.077 & 1.075 .209 & 2,88 \\
(ton karet kering) & 112.904 & 1.065 .976 & 2,20 \\
Produktivitas & 452 & 1.421 & 2,29 \\
(Kg / Ha/th) & 408 & 1.409 &
\end{tabular}


Sebagai tindak lanjut dari program tersebut telah dilaksanakan kegiatan: (1) studi karakterisasi wilayah pengembangan untuk memahami secara rinci mengenai berbagai aspek bio-fisik dan kondisi sosial ekonomi petani dan wilayahnya, sehingga terpilih tiga belas kecamatan dan enam belas desa sebagai wilayah peserta proyek; (2) sosialisasi program peremajaan; (3) pelatihan dan pendampingan; (4) pelaksanaan program demplot peremajaan dan demplot pembibitan. Dampak yang diharapkan dari penerapan model peremajaan partisipatif adalah terjadinya percepatan peremajaan karet dengan teknologi unggul secara swadaya dan berkesinambungan.

Saat ini pelaksanaan proyek ini telah berjalan lebih kurang 10 tahun. Hasil-hasil studi sebelumnya menunjukkan bahwa keberadaan suatu proyek pengembangan karet rakyat yang berhasil telah memberikan peranan yang cukup berarti dalam memperlancar proses adopsi teknologi petani dan juga menjadi sumber informasi serta media alih teknologi yang cukup berarti bagi petani di sekitarnya. Berdasarkan hal ini maka proyek yang berhasil dapat dianggap sebagai "demonstrasi plot skala besar" bagi daerah sekitarnya (Anwar et al., 1995; Supriadi et al., 1999). Oleh karena itu, untuk mengetahui bagaimana keberhasilan penerapan model peremajaan karet partisipatif, serta dampaknya (multiplier effect) terhadap perkembangan perkebunan karet rakyat di Kabupaten OKU Induk, OKU Timur dan OKU Selatan, maka perlu dilakukan studi dampak dari penerapan model peremajaan partisipatif yang telah dilaksanakan di wilayah tersebut. Tulisan ini menampilkan dampak dari penerapan model peremajaan partisipatif yang telah dilaksanakan di Kabupaten Ogan Komering Ulu, Sumatera Selatan.

\section{BAHAN DAN METODE}

Penelitian dilakukan dengan metode survei. Pemilihan responden dilakukan secara purposif yaitu memilih petani peserta program peremajaan partisipatif tahun 2003 dan petani non peserta program di sekitar proyek. Data yang dikumpulkan berupa data primer, yaitu dari wawancara dengan responden, disamping data sekunder yang diperoleh dari Dinas Perkebunan dan laporan hasil studi terdahulu. Kegiatan penelitian dilakukan di Kabupaten OKU Induk, OKU Timur dan OKU Selatan pada tahun 2014. Pemilihan lokasi dilakukan secara purposif dengan memilih lokasi yang menerapkan pola peremajaan partisipatif yang belum pernah ada proyek pengembangan karet lain selain proyek peremajaan karet partisipatif dengan pembiayaan melalui fasilitas kredit tahun 2003, yaitu:

1. Kabupaten OKU Induk : Desa Gunung Meraksa Kecamatan Lubuk Batang dan Desa Tungku Jaya Kecamatan Sosoh Buay Rayap.

2. Kabupaten OKU Timur : Desa Pelita Jaya Kecamatan Belitang Madang Raya, Desa Karang Jadi Kecamatan Belitang III, Desa Betung dan Desa Tanjung Kukuh Kecamatan Semendawai Barat.

3. Kabupaten OKU Selatan : Desa Bungin Campang Kecamatan Simpang.

Pengambilan responden dilakukan secara acak sederhana sebanyak sepuluh orang peserta proyek dan lima orang non peserta proyek di masing-masing desa. Selanjutnya dilakukan analisis diskriptif, dengan membandingkan kondisi perkebunan karet dan sosial ekonomi petani pada saat sebelum dan sesudah penerapan pola peremajaan karet partisipatif. Analisis juga dilakukan dengan membandingkan Selanjutnya survei juga dilaksanakan di Desa Tungku Jaya Kabupaten OKU Induk, Desa Pelita Jaya dan Desa Karang Jadi Kabupaten OKU Timur yang sebagian besar penduduknya adalah penduduk pendatang, sehingga dalam analisis disebut "Desa pendatang".dampak penerapan pola peremajaan partisipatif peserta proyek di desa lokal dan desa pendatang.

Penelitian dilakukan di empat desa lokal yaitu Desa Bungin Campang Kabupaten OKU Selatan, Desa Gunung Meraksa Kabupaten OKU Induk, Desa Tanjung Kukuh dan Desa Betung Kabupaten OKU Timur. Mayoritas penduduk di empat desa tersebut adalah penduduk lokal sehingga dalam analisis disebut "Desa lokal". 


\section{HASIL DAN PEMBAHASAN}

\section{Dampak Peremajaan Partisipatif di Tingkat Desa}

Data di tingkat desa menunjukkan bahwa sejak adanya proyek peremajaan partisipatif telah terjadi perluasan areal karet swadaya. Di Desa Tungku Jaya awalnya sebagian besar penduduk adalah petani jeruk, namun saat ini mayoritas penduduknya adalah petani karet (Tabel 2). Adanya proyek partisipatif juga telah mendorong terjadinya peningkatan adopsi teknologi di desa pendatang (Tabel 3). Tingkat adopsi klon unggul lebih tinggi di desa pendatang dibandingkan dengan desa lokal. Hal ini dikarenakan sebagian besar petani di desa pendatang ketika mulai mengenal tanaman karet langsung diperkenalkan dengan tanaman karet klonal. Dampaknya hingga saat ini, hampir seluruh petani di desa pendatang $(97 \%)$ menanam tanaman karet klonal. Sedangkan di desa lokal masih terdapat tanaman karet muda yang merupakan tanaman seedling (Tabel 3).

Tabel 2. Profil desa

Table 2. Profile of villages

\begin{tabular}{lcc}
\hline \multicolumn{1}{c}{$\begin{array}{c}\text { Uraian } \\
\text { Discription }\end{array}$} & $\begin{array}{c}\text { Desa lokal } \\
\text { Local village }\end{array}$ & $\begin{array}{c}\text { Desa pendatang } \\
\text { Migrants village }\end{array}$ \\
\hline Luas desa (Ha) & 6.133 & 1.690 \\
Luas karet (Ha) & & \\
- Proyek & 37 & 162 \\
- Swadaya & 1.300 & 277 \\
Petani karet (\%) & 65 & 93 \\
Kepala keluarga & 661 & 421 \\
\hline
\end{tabular}

Sumber (Source) : data primer (primary data)

Tabe1 3. Tingkat adopsi teknologi karet di tingkat desa

Table 3. Adoption level of rubber technology in the villages

\begin{tabular}{lcccc}
\hline \multirow{2}{*}{$\begin{array}{c}\text { Teknologi } \\
\text { Technology }\end{array}$} & \multicolumn{2}{c}{$\begin{array}{c}\text { Lokal } \\
\text { (\%) }\end{array}$} & \multicolumn{2}{c}{$\begin{array}{c}\text { Pendatang } \\
\text { Migrants } \\
(\%)\end{array}$} \\
\cline { 2 - 5 } & $\begin{array}{c}\text { Setelah } \\
\text { After }\end{array}$ & $\begin{array}{c}\text { Sebelum } \\
\text { Before }\end{array}$ & $\begin{array}{c}\text { Setelah } \\
\text { After }\end{array}$ & $\begin{array}{c}\text { Sebelum } \\
\text { Before }\end{array}$ \\
\hline Klon & 77 & 17 & 97 & 60 \\
Jarak tanam & 100 & 48 & 100 & 62 \\
Lubang tanam & 83 & 40 & 100 & 62 \\
Pemeliharaan & & & & 38 \\
- Pemupukan & 95 & 35 & 100 & 0 \\
- Pengendalian penyakit & 12 & 0 & 40 & $N A$ \\
- Pengendalian hama & 100 & $N A$ & 100 & $N A$ \\
- Pengendalian gulma & 93 & $N A$ & 100 & \\
\hline
\end{tabular}

Keterangan (Remaks): NA : data tidak tersedia (data was not available)

Dampak Proyek Partisipatif di Tingkat Petani Peserta Proyek

Hasil pengamatan menunjukkan bahwa adanya proyek peremajaan partisipatif telah mendorong penambahan luas areal karet klonal swadaya milik petani baik untuk tanaman belum menghasilkan (TBM) maupun tanaman yang menghasilkan (TM) (Tabel 4). Data pada
Tabel 4 menunjukkan bahwa lebih dari $67 \%$ petani di desa lokal maupun di desa pendatang telah memiliki kebun karet TBM okulasi swadaya dengan luasan rata-rata 1,7 Ha per petani di desa lokal dan $2 \mathrm{Ha}$ per petani di desa pendatang. Pada saat pengamatan, tidak ada lagi tanaman seedling untuk lahan TBM di desa pendatang. Sedangkan di desa lokal masih terdapat sekitar $17 \%$ petani yang menanam 
Tabel 4. Luas kepemilikan lahan karet swadaya di tingkat petani

Table 4. Total rubber area owned by smallholders

\begin{tabular}{lcc}
\hline $\begin{array}{c}\text { Penambahan aset kebun } \\
\text { Increase of field asset }\end{array}$ & $\begin{array}{c}\text { Lokal } \\
\text { Local }\end{array}$ & $\begin{array}{c}\text { Pendatang } \\
\text { Migrants }\end{array}$ \\
\hline \multicolumn{2}{c}{ Pemilikan kebun swadaya (Ha) } & 14 \\
\hline 1. TBM (Tanaman Belum Menghasilkan) & 17 & \\
- Okulasi & $1,7(67 \%)$ & $2,0(75 \%)$ \\
- Seedling & $0,5(17 \%)$ & $0(0 \%)$ \\
2. TM (Tanaman Menghasilkan) & & \\
- Okulasi & $1,25(60 \%)$ & $1,0(70 \%)$ \\
- Seedling & $1(15 \%)$ & $1,0(10 \%)$ \\
\hline
\end{tabular}

tanaman seedling. Untuk lahan karet TM, sekitar $60 \%$ petani di desa lokal telah memiliki tanaman okulasi dengan luasan $1,25 \mathrm{Ha}$ per petani. Sedangkan di desa pendatang, jumlah petani yang telah memiliki kebun karet okulasi telah mencapai $70 \%$ dengan luasan $1 \mathrm{Ha}$ per petani.

Selanjutnya proyek partisipatif telah memberikan dampak terhadap peningkatan pengetahuan dan adopsi teknologi perkaretan pada peserta proyek apabila dibandingkan pada saat sebelum penerapan proyek. Tingkat pengetahuan dan adopsi yang diamati meliputi teknologi bahan tanam, penanaman dan pemeliharaan. Namun dari analisis, tingkat pengetahuan dan adopsi petani terhadap pengendalian penyakit tanaman karet masih rendah (Tabel 5).

\section{Dampak Proyek Partisipatif di Tingkat Petani Non Peserta Proyek}

Proyek partisipatif juga berdampak terhadap peningkatan pengetahuan dan adopsi petani non peserta proyek. Hasil analisis menunjukkan bahwa tingkat pengetahuan dan adopsi petani non peserta tidak jauh berbeda dibandingkan petani peserta proyek. Tingkat pengetahuan dan adopsi petani non proyek terhadap pengendalian penyakit masih sangat rendah (Tabel 6).
Gambar 1 menunjukkan kodisi kebun petani non proyek yang telah mengadopsi teknologi karet yang dianjurkan.

\section{Pelunasan Kredit dan Akses Perbankan di Tingkat Petani Peserta Proyek}

Pola pembiayaan kegiatan peremajaan karet partisipatif di Kabupaten OKU menggunakan dana perbankan (Skim Kredit Khusus) dengan penyediaan kebutuhan dana untuk pembangunan kebun peremajaan petani yaitu melalui pinjaman kredit lunak jangka panjang Bank Sumsel. Penyediaan kredit tersebut dimungkinkan karena Pemerintah Daerah Kabupaten OKU menyimpan sejumlah dana di Bank Sumsel dalam bentuk simpanan giro tetap (dana beku) selama pinjaman petani berlangsung. Jaminan untuk pinjaman kredit tersebut adalah sertifikat kebun karet atas nama petani peserta yang diserahkan kepada pihak bank dan akan dikembalikan setelah pelunasan kredit. Pembayaran angsuran kredit sebesar 25\% sampai dengan $30 \%$ dari nilai bruto hasil penjualan karet yang disetorkan kepada Bank Sumsel (Supriadi et al., 2003).

Terkait dengan pelunasan kredit tersebut hasil pengamatan menunjukkan bahwa masih banyak petani peserta proyek yang belum melunasi kreditnya. Akibatnya masih banyak sertifikat kebun petani yang belum dikembalikan oleh pihak Bank (Tabel 7). Permasalahan ini terjadi dikarenakan 
Tabe1 5. Tingkat pengetahuan dan adopsi petani peserta proyek terhadap teknologi karet Table 5. Knowledge and adoption levels of participant farmers to rubber technology

\begin{tabular}{|c|c|c|c|c|c|c|c|c|}
\hline \multirow{3}{*}{$\begin{array}{l}\text { Teknologi } \\
\text { Technology }\end{array}$} & \multicolumn{4}{|c|}{$\begin{array}{l}\text { Setelah proyek } \\
\text { After the project } \\
(\%)\end{array}$} & \multicolumn{4}{|c|}{$\begin{array}{c}\text { Sebelum proyek } \\
\text { Before the project } \\
(\%)\end{array}$} \\
\hline & \multicolumn{2}{|c|}{$\begin{array}{l}\text { Lokal } \\
\text { Local }\end{array}$} & \multicolumn{2}{|c|}{$\begin{array}{c}\text { Pendatang } \\
\text { Migrants }\end{array}$} & \multicolumn{2}{|c|}{$\begin{array}{l}\text { Lokal } \\
\text { Local }\end{array}$} & \multicolumn{2}{|c|}{$\begin{array}{l}\text { Pendatang } \\
\text { Migrants }\end{array}$} \\
\hline & $\mathrm{P}$ & $\mathrm{A}$ & $\mathrm{P}$ & $\mathrm{A}$ & $\mathrm{P}$ & $\mathrm{A}$ & $\mathrm{P}$ & A \\
\hline $\begin{array}{l}\text { Bahan Tanam } \\
\text { - Okulasi } \\
\text { - Jenis klon } \\
\text { - Cara okulasi }\end{array}$ & $\begin{array}{l}93 \\
75 \\
49 \\
\end{array}$ & $\begin{array}{l}80 \\
80 \\
49 \\
\end{array}$ & $\begin{array}{l}90 \\
65 \\
57\end{array}$ & $\begin{array}{l}79 \\
92 \\
76 \\
\end{array}$ & $\begin{array}{l}65 \\
22 \\
22 \\
\end{array}$ & $\begin{array}{l}41 \\
21 \\
20\end{array}$ & $\begin{array}{l}41 \\
17 \\
14\end{array}$ & $\begin{array}{r}17 \\
11 \\
7\end{array}$ \\
\hline $\begin{array}{l}\text { Penanaman } \\
\text { - Jarak tanam } \\
\text { - Lubang tanam } \\
\text { - Pemupukan } \\
\text { - Pewiwilan } \\
\text { - Pembentukan tajuk }\end{array}$ & $\begin{array}{r}100 \\
100 \\
93 \\
100 \\
100 \\
\end{array}$ & $\begin{array}{r}100 \\
90 \\
87 \\
100 \\
100 \\
\end{array}$ & $\begin{array}{l}100 \\
100 \\
100 \\
100 \\
100\end{array}$ & $\begin{array}{l}100 \\
100 \\
100 \\
100 \\
100 \\
\end{array}$ & $\begin{array}{l}62 \\
49 \\
42 \\
57 \\
51\end{array}$ & $\begin{array}{l}48 \\
40 \\
35 \\
50 \\
46\end{array}$ & $\begin{array}{l}37 \\
24 \\
17 \\
31 \\
30\end{array}$ & $\begin{array}{l}28 \\
15 \\
13 \\
24 \\
24\end{array}$ \\
\hline $\begin{array}{l}\text { Pemeliharaan } \\
\text { - Pengendalian penyakit } \\
\text { - Pengendalian gulma } \\
\text { - Pengendalian hama }\end{array}$ & $\begin{array}{l}67 \\
93 \\
85\end{array}$ & $\begin{array}{l}42 \\
93 \\
75\end{array}$ & $\begin{array}{r}70 \\
100 \\
93\end{array}$ & $\begin{array}{r}55 \\
100 \\
85\end{array}$ & NA & NA & NA & NA \\
\hline
\end{tabular}

Tabel 6. Tingkat pengetahuan dan adopsi petani non peserta proyek dibandingkan peserta proyek

Table 6. Non-participant farmers' knowledge and adoption level compared to participants farmers

\begin{tabular}{|c|c|c|c|c|c|c|c|c|}
\hline \multirow{3}{*}{$\begin{array}{l}\text { Teknologi } \\
\text { Technology }\end{array}$} & \multicolumn{4}{|c|}{$\begin{array}{c}\text { Peserta proyek } \\
\text { Participants } \\
(\%)\end{array}$} & \multicolumn{4}{|c|}{$\begin{array}{c}\text { Non proyek } \\
\text { Non-Participants } \\
(\%)\end{array}$} \\
\hline & \multicolumn{2}{|c|}{$\begin{array}{l}\text { Lokal } \\
\text { Local }\end{array}$} & \multicolumn{2}{|c|}{$\begin{array}{c}\text { Pendatang } \\
\text { Migrants }\end{array}$} & \multicolumn{2}{|c|}{$\begin{array}{l}\text { Lokal } \\
\text { Local }\end{array}$} & \multicolumn{2}{|c|}{$\begin{array}{c}\text { Pendatang } \\
\text { Migrants }\end{array}$} \\
\hline & $\mathrm{P}$ & $\mathrm{A}$ & $\mathrm{P}$ & $\mathrm{A}$ & $\mathrm{P}$ & $\mathrm{A}$ & $\mathrm{P}$ & $\mathrm{A}$ \\
\hline $\begin{array}{l}\text { Bahan Tanam } \\
\text { - Okulasi } \\
\text { - Jenis klon } \\
\text { - Cara okulasi } \\
\end{array}$ & $\begin{array}{l}93 \\
75 \\
49 \\
\end{array}$ & $\begin{array}{l}80 \\
80 \\
49 \\
\end{array}$ & $\begin{array}{l}90 \\
65 \\
57\end{array}$ & $\begin{array}{l}79 \\
92 \\
76 \\
\end{array}$ & $\begin{array}{l}90 \\
60 \\
35 \\
\end{array}$ & $\begin{array}{l}70 \\
70 \\
20 \\
\end{array}$ & $\begin{array}{l}90 \\
60 \\
40 \\
\end{array}$ & $\begin{array}{l}75 \\
85 \\
30 \\
\end{array}$ \\
\hline $\begin{array}{l}\text { Penanaman } \\
\text { - Jarak tanam } \\
\text { - Lubang tanam } \\
\text { - Pemupukan } \\
\text { - Pewiwilan } \\
\text { - Pembentukan tajuk }\end{array}$ & $\begin{array}{r}100 \\
100 \\
93 \\
100 \\
100 \\
\end{array}$ & $\begin{array}{r}100 \\
90 \\
87 \\
100 \\
100 \\
\end{array}$ & $\begin{array}{l}100 \\
100 \\
100 \\
100 \\
100 \\
\end{array}$ & $\begin{array}{l}100 \\
100 \\
100 \\
100 \\
100 \\
\end{array}$ & $\begin{array}{r}100 \\
100 \\
90 \\
100 \\
90 \\
\end{array}$ & $\begin{array}{r}85 \\
85 \\
75 \\
100 \\
100 \\
\end{array}$ & $\begin{array}{l}100 \\
100 \\
100 \\
100 \\
100 \\
\end{array}$ & $\begin{array}{l}100 \\
100 \\
100 \\
100 \\
100\end{array}$ \\
\hline $\begin{array}{l}\text { Pemeliharaan } \\
\text { - Pengendalian penyakit } \\
\text { - Pengendalian gulma } \\
\text { - Pengendalian hama }\end{array}$ & $\begin{array}{l}67 \\
93 \\
85 \\
\end{array}$ & $\begin{array}{l}42 \\
93 \\
75 \\
\end{array}$ & $\begin{array}{r}70 \\
100 \\
93 \\
\end{array}$ & $\begin{array}{r}55 \\
100 \\
85 \\
\end{array}$ & $\begin{array}{l}15 \\
90 \\
75 \\
\end{array}$ & $\begin{array}{r}0 \\
90 \\
65 \\
\end{array}$ & $\begin{array}{r}0 \\
90 \\
70 \\
\end{array}$ & $\begin{array}{r}0 \\
100 \\
70 \\
\end{array}$ \\
\hline
\end{tabular}

Keterangan (Remaks) : P : Pengetahuan (Knowledge); A : Adopsi (Adoption); NA : Data tidak tersedia (data was not available) 


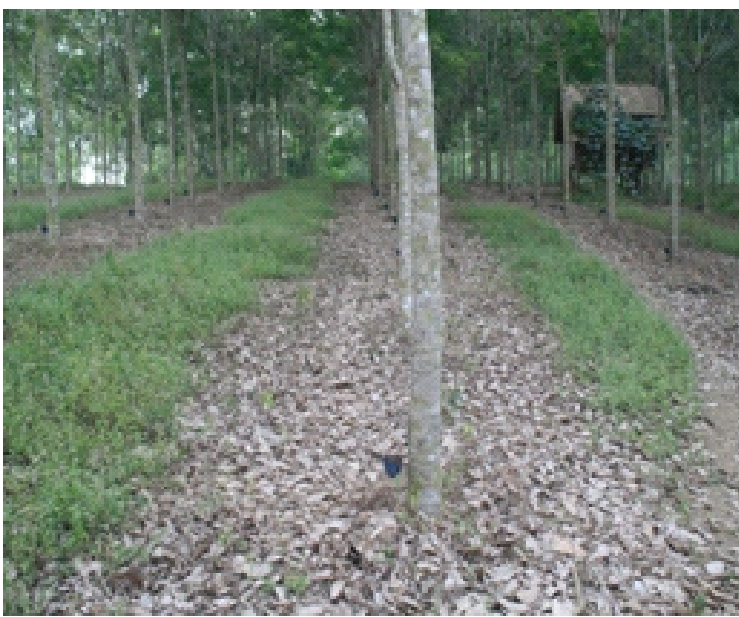

a. Desa pendatang

a. Migrant Village

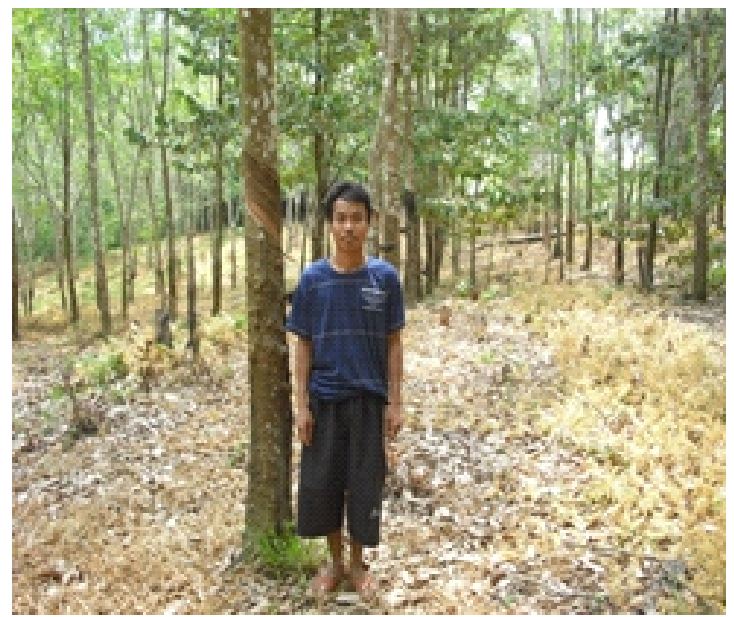

b. Desa Lokal

b. Local Village

Gambar 1. Kondisi kebun petani non proyek

Figure 1. Condition of non participant's farmers

Tabel 7. Pelunasan kredit dan akses perbankan di tingkat petani peserta proyek Table 7. The acquittance of credit and banking access in participants level

\begin{tabular}{lcr}
\hline & $\begin{array}{c}\text { Desa lokal } \\
\text { Local village }\end{array}$ & $\begin{array}{c}\text { Desa pendatang } \\
\text { Migrants village }\end{array}$ \\
\hline & Pembayaran Kredit & 75 \\
\hline Lunas (\%) & 62 & 4.300 .000 \\
Sisa kredit (IDR) & 4.500 .000 & 75 \\
\hline Terbit (\%) & 62 & 25 \\
Belum terbit (\%) & 38 & 60 \\
\hline Aktif (\%) & Sertifikat Kebun & 40 \\
Tidak aktif (\%) & 68 & \\
\hline
\end{tabular}

pembayaran angsuran kredit yang disetorkan kepada bank yang seharusnya melalui mekanisme petugas proyek, kelompok tani atau koperasi tidak berjalan sebagaimana mestinya sehingga hal tersebut menjadi alasan petani peserta belum membayar angsuran kreditnya. Petani yang sudah melunasi kredit umumnya sudah mulai aktif dalam akses perbankan karena sudah memiliki sertifikat kebun yang bisa dijadikan sebagai agunan untuk melakukan peminjaman uang di bank.

\section{Kondisi Keragaan Kebun Karet Peserta dan Non Peserta Proyek}

Hasil pengamatan kondisi kebun peserta proyek dan non peserta proyek, menunjukkan bahwa secara umum keterampilan petani dalam hal penyadapan masih sangat rendah. Kondisi ini disebabkan sebelum buka sadap, petani tidak dibekali dengan pelatihan penyadapan. Konsumsi kulit yang boros umumnya banyak terjadi, dikarenakan tanaman karet disadap setiap hari. Hal ini ditunjukkan oleh hasil pengamatan pada 
bidang sadap. Pada saat ini tanaman sedang memasuki tahun keenam masa sadap (TM6) yang seharusnya tanaman masih disadap pada panel B0-1. Namun kenyataannya tanaman sudah disadap pada panel B0-2, bahkan ada diantaranya tanaman karet yang telah disadap hingga panel B1-1. Selain itu luka kayu juga banyak terdapat pada panel sadap dengan ukuran yang cukup besar (Tabel 8 dan Gambar 2). Akibat dari sadap berat tersebut, banyak tanaman karet yang terkena penyakit kering alur sadap (KAS) terutama pada kebun proyek di desa lokal (Tabel 9).

\section{Keberlanjutan Program}

Pola peremajaan partisipatif telah memberikan manfaat positif bagi pengembangan karet rakyat di Kabupaten OKU. Oleh karena itu, Pemerintah Daerah setempat telah banyak memfasilitasi kebijakan program pengembangan karet melalui pembiayaan program bantuan bibit untuk kebun usaha tani dan kebun pembibitan. Berikut ini program-program yang sudah dilaksanakan oleh Pemerintah setempat bagi pengembangan karet di Kabupaten OKU (Tabel 10 dan 11). Selain bantuan bibit untuk kebun usaha tani serta bantuan kebun entres dan batang bawah untuk kebun pembibitan, Pemerintah juga telah memfasilitasi program pelatihan peningkatan kualitas kelembagaan dan sumber daya manusia serta pelatihan budidaya tanaman karet bagi petani dan petugas.

Model peremajaan karet partisipatif telah diaplikasikan di beberapa sentra karet di Indonesia. Namun, untuk daerah-daerah dimana Pemerintah Daerah tidak memiliki dana beku dapat dilakukan dengan pemberian sarana pendukung untuk kegiatan pembangunan dan pemeliharaan kebun misalnya dengan penyediaan jasa informasi, penyuluhan, pendampingan dan asistensi untuk petani; penyediaan bahan tanam bagi petani melalui pengembangan penangkar serta pengembangan kelompok pembibitan di lokasi petani; dan penyediaan jasa pemasaran melalui kemitraan dengan pelaku bisnis terkait.

Tabel 8. Kondisi bidang sadap di kebun peserta dan non peserta proyek

Table 8. The condition of tapping panel in participant and non participants

\begin{tabular}{|c|c|c|c|c|}
\hline \multirow{2}{*}{$\begin{array}{l}\text { Kondisi bidang sadap } \\
\text { Condition of tapping } \\
\text { panel }\end{array}$} & \multicolumn{2}{|c|}{$\begin{array}{l}\text { Proyek } \\
\text { Project }\end{array}$} & \multicolumn{2}{|c|}{$\begin{array}{l}\text { Non proyek } \\
\text { Non-project }\end{array}$} \\
\hline & $\begin{array}{l}\text { Lokal } \\
\text { Local }\end{array}$ & $\begin{array}{c}\text { Pendatang } \\
\text { Migrants }\end{array}$ & $\begin{array}{l}\text { Lokal } \\
\text { Local }\end{array}$ & $\begin{array}{c}\text { Pendatang } \\
\text { Migrants }\end{array}$ \\
\hline \multicolumn{5}{|c|}{ Luka kayu } \\
\hline - Kecil $(1 \times 0,6) \mathrm{cm}$ & 10 & 30 & 0 & 15 \\
\hline - Sedang $(1,5 \times 3) \mathrm{cm}$ & 30 & 30 & 30 & 35 \\
\hline - Besar $(>1,5 \times 3) \mathrm{cm}$ & 60 & 40 & 70 & 50 \\
\hline \multicolumn{5}{|c|}{ Konsumsi kulit (cm) } \\
\hline$-\mathrm{BO}-1$ & 134 & 133 & 133 & 143 \\
\hline - BO-2 & 125 & 103 & 106 & 144 \\
\hline$-\mathrm{B} 1-1$ & 31 & 16 & 35 & \\
\hline \multicolumn{5}{|c|}{ Sudut irisan sadap (\%) } \\
\hline - Benar & 75 & 60 & 75 & 60 \\
\hline - Salah & 25 & 40 & 25 & 40 \\
\hline \multicolumn{5}{|c|}{ Tinggi bukaan sadap } \\
\hline$-130 \mathrm{~cm}$ & 15 & 30 & 5 & 10 \\
\hline$->$ atau $<130 \mathrm{~cm}$ & 85 & 70 & 95 & 90 \\
\hline
\end{tabular}




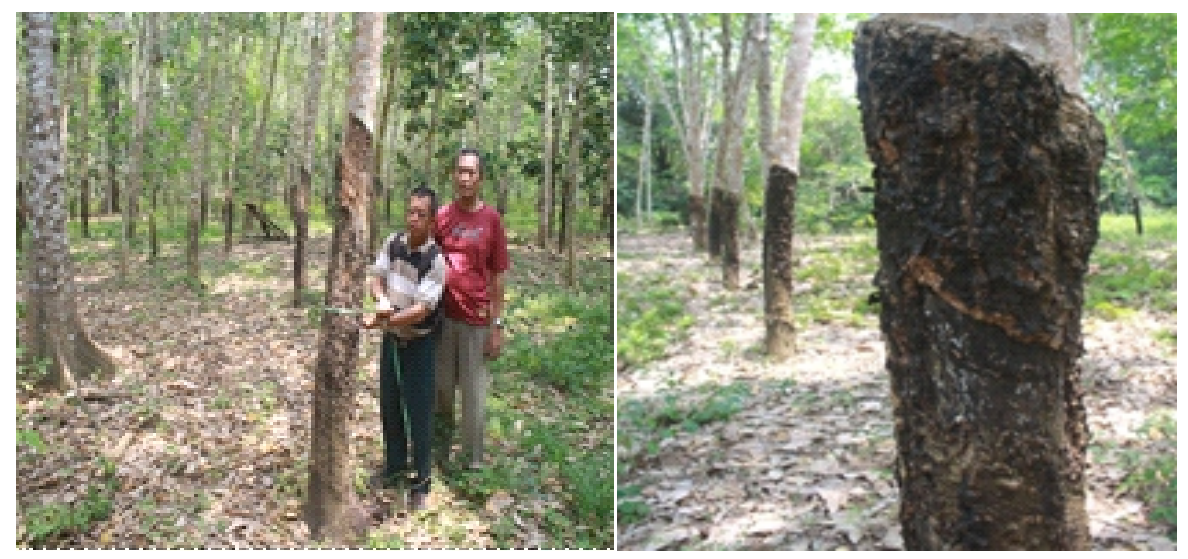

a. Desa Lokal

(Local Village)

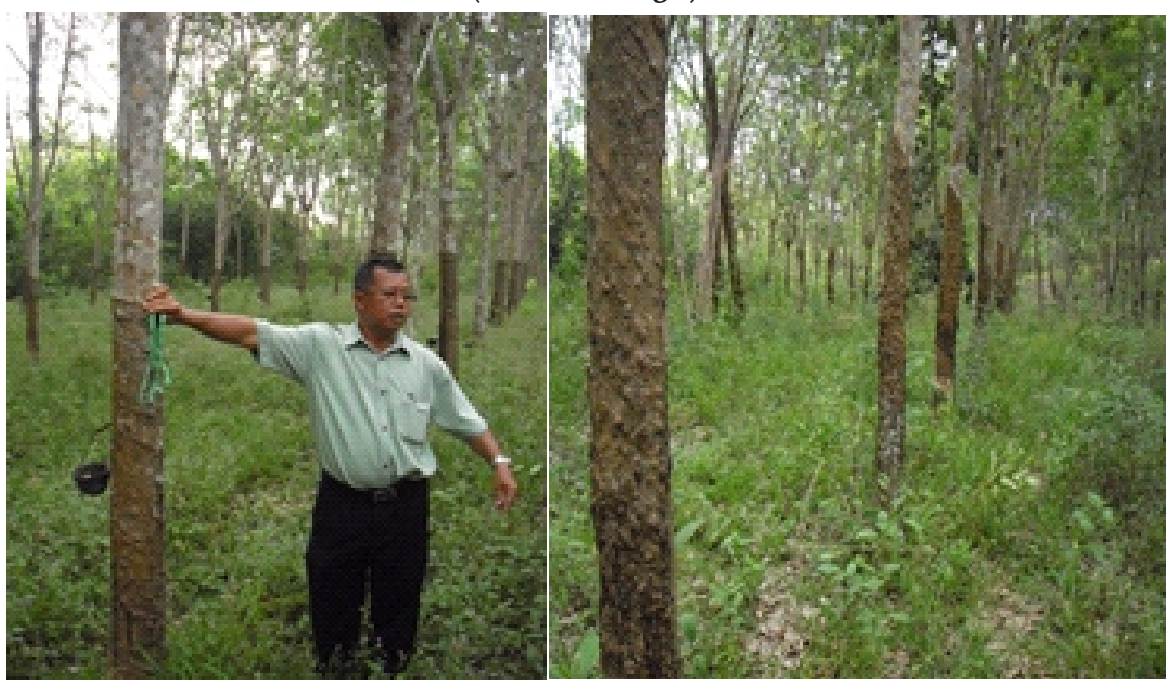

b. Desa pendatang

(Migrant Village)

Gambar 2. Kondisi kebun dan bidang sadap di kebun petani proyek Figure 2. The condition of tapping panel in participant farmers'

Tabel 9. Kondisi keragaan kebun TM proyek dan non proyek

Table 9. The condition of mature rubber plant int theparticipants and non participants' farmers

\begin{tabular}{lcccc}
\hline \multirow{2}{*}{$\begin{array}{c}\text { Uraian } \\
\text { Discription }\end{array}$} & \multicolumn{2}{c}{$\begin{array}{c}\text { Proyek } \\
\text { Project }\end{array}$} & \multicolumn{2}{c}{$\begin{array}{c}\text { Non proyek } \\
\text { Non-project }\end{array}$} \\
\cline { 2 - 5 } & $\begin{array}{c}\text { Lokal } \\
\text { Local }\end{array}$ & $\begin{array}{c}\text { Pendatang } \\
\text { Migrants }\end{array}$ & $\begin{array}{c}\text { Lokal } \\
\text { Local }\end{array}$ & $\begin{array}{c}\text { Pendatang } \\
\text { Migrants }\end{array}$ \\
\hline & Keragaan tanaman (\%) & & \\
\hline Lilit batang (cm) & 59 & 57 & 59 & 49 \\
Jumlah KAS & 22 & 12 & 30 & 3 \\
Jumlah JAP & 10 & 1 & 0 & 1 \\
\hline & Kebersihan kebun (\%) & & 0 \\
\hline - Bersih & 65 & 29 & 0 & 70 \\
- Sedang & 30 & 66 & 20 & 30 \\
- Kotor & 5 & 5 & 80 & \\
\hline
\end{tabular}


Tabel 11. Data program pengembangan pembibitan karet di Kabupaten OKU Timur Table 11. Data of rubber nursery development program in OKU Timur District

\begin{tabular}{ccc}
\hline $\begin{array}{c}\text { Tahun } \\
\text { Year }\end{array}$ & $\begin{array}{c}\text { Entres } \\
\text { Budwood garden } \\
(\text { Ha) }\end{array}$ & $\begin{array}{c}\text { Batang bawah } \\
\text { (Batang) } \\
\text { Rootstock nursery } \\
\text { (Stump) }\end{array}$ \\
\hline 2006 & 1 & 10.500 \\
2007 & 1 & 10.000 \\
2014 & - & 75.000 \\
\hline
\end{tabular}

Sumber (Source): Disbun OKU Timur, 2013

Tabel 10. Data bantuan bibit karet untuk peremajaan kebun karet di Kabupaten OKU Timur

Table 10. Data of planting material assistance from Government for rubber replanting in OKU Timur District

\begin{tabular}{|c|c|c|c|c|}
\hline \multirow{3}{*}{$\begin{array}{l}\text { Tahun } \\
\text { Year }\end{array}$} & \multicolumn{2}{|c|}{$\begin{array}{c}\text { APBD I } \\
\text { Local Government Budget I }\end{array}$} & \multicolumn{2}{|c|}{$\begin{array}{c}\text { APBD II } \\
\text { Local Government Budget II }\end{array}$} \\
\hline & $\begin{array}{l}\text { Jumlah bibit } \\
\text { (Batang) }\end{array}$ & & $\begin{array}{l}\text { Jumlah bibit } \\
\text { (Batang) }\end{array}$ & \\
\hline & $\begin{array}{c}\text { Number of } \\
\text { planting material } \\
\text { (Stump) }\end{array}$ & $\begin{array}{l}\text { Luas } \\
\text { Area } \\
\text { (Ha) }\end{array}$ & $\begin{array}{c}\text { Number of } \\
\text { planting material } \\
\text { (Stump) }\end{array}$ & $\begin{array}{l}\text { Luas } \\
\text { Area } \\
\text { (Ha) }\end{array}$ \\
\hline 2004 & 25.000 & 50 & 0 & 0 \\
\hline 2005 & 75.000 & 150 & 1.250 .000 & 2.500 \\
\hline 2006 & 135.000 & 270 & 1.250 .000 & 2.500 \\
\hline 2007 & 350.000 & 700 & 1.250 .000 & 2.500 \\
\hline 2008 & 200.000 & 400 & 1.250 .000 & 2.500 \\
\hline 2009 & 100.000 & 200 & 1.250 .000 & 2.500 \\
\hline 2010 & 25.000 & 50 & 1.000 .000 & 2.000 \\
\hline 2011 & 25.000 & 50 & 0 & 0 \\
\hline 2012 & 55.000 & 110 & 1.000 .000 & 2.000 \\
\hline 2013 & 0 & 0 & 0 & 0 \\
\hline 2014 & 125.000 & 250 & 0 & 0 \\
\hline
\end{tabular}

Sumber (Source): Disbun Kabupaten OKU Timur, 2013 


\section{KESIMPULAN}

Dari hasil pengamatan disimpulkan bahwa proyek peremajaan partisipatif yang telah diterapkan di Kabupaten OKU telah memberikan dampak positif terhadap petani peserta proyek dan lingkungan sekitarnya, hal ini dilihat dari:

- Peningkatan luas areal penanaman karet swadaya di desa

- Bertambahnya areal karet klonal yang dimiliki petani

- Peningkatan pengetahuan dan adopsi petani baik peserta maupun non peserta terhadap teknologi perkaretan

- Peningkatan pengetahuan petani dalam akses perbankan

Petani perlu dibekali pelatihan terutama mengenai penyadapan dan pengendalian penyakit karet. Dalam hal keberlanjutan program peremajaan, Pemerintah Daerah setempat telah banyak memfasilitasi kebijakan program pengembangan karet melalui pembiayaan program bantuan bibit untuk kebun usaha tani dan kebun pembibitan, serta pelatihan bagi para petugas teknis dan petani karet. Mengingat dampak model ini yang baik bagi pengembangan karet rakyat, model ini perlu dikembangkan di sentra karet lainnya.

\section{DAFTAR PUSTAKA}

Anwar, C., Nancy, C., \& Hendratno, S. (1995). Studi Perkembangan Adopsi Budidaya Karet pada Beberapa Proyek Pengembangan Karet di Sumatera Selatan. Laporan Hasil Penelitian Balai Penelitian Sembawa. Palembang, Indonesia: Balai Penelitian Sembawa.

Badan Pusat Statistik. (2013). Statistik karet Indonesia 2013. Jakarta, Indonesia: BPS.

Dinas Perkebunan Provinsi Sumatera Selatan. (2013). Statistik perkebunan 2013. Palembang, Indonesia: Dinas Perkebunan Provinsi Sumatera Selatan.
Dinas Perkebunan Kabupaten OKU Timur. (2013). Laporan Tahunan Dinas Perkebunan Kabupaten OKU Timur, OKU Timur, Indonesia: Disbun Kabupaten OKU Timur.

Direktorat Jendral Perkebunan. (2014). Statistik perkebunan: Karet. Jakarta, Indonesia: Ditjenbun.

Gabungan Perusahaan Karet Indonesia. (2014). Data ekspor karet alam Indonesia menurut jenis mutu periode Desember 2013. Jakarta, Indonesia: Gapkindo.

Hendratno, S., Woelan, S., \& Fathurrohman, M.I. (2015). Analisis kelayakan finansial model peremajaan karet partisipatif: Sumber pembiayaan dari hasil penjualan kayu karet. Warta Perkaretan, 34(1), 55-64.

Pemerintah Provinsi Sumatera Selatan. (2012). Program pembangunan perkebunan Sumatera Selatan. Palembang, Indonesia: Pemda Provinsi Sumsel.

Supriadi, M., Wibawa, G., \& Nancy, C. (1999). Percepatan peremajaan karet melalui penerapan teknologi dan pemberdayaan masyarakat perkebunan. Prosiding Lokakarya dan Ekspose Teknologi Perkebunan. Buku I. Model Peremajaan Karet Rakyat Secara Swadaya (p. 45-69). Palembang, Indonesia: AP2I.

Supriadi, M., Nancy, C., Gunawan, A., Boerhendhy, I., Rosyid, M. J., \& Lasminingsih, M. (2003). Laporan Studi Karakterisasi Calon Petani Peserta Proyek Peremajaan Karet Partisipatif di Kabupaten OKU, Sumatera Selatan. Laporan Hasil Penelitian. Palembang, Indonesia: Balai Penelitian Sembawa. 
Supriadi, M., \& Nancy, C. (2005). Model peremajaan karet partisipatif: perkembangan dan tantangan penerapannya. Warta Perkaretan, $24(1), 1-13$.
Supriadi, M., Nancy, C., Wibawa, G., \& Gunawan, A. (2006). Pedoman umum penerapan model peremajaan karet partisipatif. Palembang, Indonesia: Balai Penelitian Sembawa. 